\title{
THE BASIS FOR A CONSTRUCTIVE RELATIONSHIP BETWEEN MANAGEMENT CONSULTANTS AND CLIENTS (SMEs)
}

\author{
Renato Lopes da COSTA (D) 1 , Álvaro Lopes DIAS (1)2*, Leandro PEREIRA (D) ${ }^{2}$, \\ José SANTOS ${ }^{1}$, Isabel MIGUEL(iD) 1 \\ 1, 2ISCTE, DMOGG and BRU, Av. das Forças Armadas, Lisbon, Portugal \\ ${ }^{2}$ Universidade Lusófona, Eceo, Campo Grande 376, Lisbon, Portugal
}

Received 6 January 2020; accepted 1 April 2020

\begin{abstract}
In a historical retrospective, although the existing literature calls the management consulting industry an extraordinary sector and a unique phenomenon in the business context, in fact these statements are not accompanied by a number of academic studies that emphasize the importance of the effective management consultant's work. To battle the lack of studies in this emerging area, this article aims to understand the most important factors from the perspective of consultants and managers to build successful relationships in management consulting projects. Semi-structured interviews and questionnaires were conducted to management consultants and SME managers. Our findings suggests competence and experience of consultants, their ability to understand clients, their professionalism and credibility, the transparency of the processes, values and goals they can put in the performance of their work are the five key factors for building successful relationships.
\end{abstract}

Keywords: management consulting, relationships, strategy-as-practice.

JEL Classification: L22, L25.

\section{Introduction}

Management consultancy can be defined as "the process by which an individual or a firm assists a client to achieve a stated outcome" (Biech, 2019, p. 3). In the same line of other fields of the management territory, the evolution of the strategic subjects in organizations has broadly been diffused by the management consulting industry, this being the main reason why Canback (1998) describes this sector successful way which must be embraced by companies in the contextualization of their strategic orientation and their professionals as being the true disseminators of the complex phenomenon of business evolution known until today.

These opinions have been supported by several authors over the past few years, defending the industry as an influential and powerful tool for organizational change, bringing a new life to organizations and their procedural chains.

Retrospectivly, the benefits of the management consulting industry were already clear in terms of influence and contribution they generated to the growth of industries in the 1950s (Stryker, 1954). For this same reason,
Drucker (1979) names it twenty-five years later as an extraordinary sector and a unique phenomenon in the business context and not only by being a unique, singular, objective and independent aid that translates into the resolution of concrete problems (Greiner \& Metzger, 1983; Canback, 1999), but also by the experience that it transports and is many times associated to results related to high productivity (Fincham, 2010).

At an international level, although the progress and heterogeneity of scientific studies carried out in recent decades in the area of strategic consulting by prestigious authors such as Sturdy (2009), Kaiser and Kampe (2005), McGivern (1983), McLarty and Robinson (1998), Fincham et al. (2008), Karantinou and Hogg (2009), Werr and Styhre (2002), Jackall (1988), Clark (2004), Jarzabkowski and Spee (2009), Whittington (2007) and Lundgreen and Blom (2009), a fact is that that here too the workers of the strategy have not received much attention in the strategic field of research. Wittington (2007) gives an example, noting that no article on consulting in one of the major journals of the strategy such as the "Strategy Management Journal" had been published by 2007.

${ }^{*}$ Corresponding author. E-mail: alvaro.dias1@gmail.com 
In a more practical component, recent strategy-aspractice (SAP) movement has implied some attention to the importance of consultants (Whittington, 2006; Jarzabkowski et al., 2007; Jarzabkowski \& Spee, 2005; Kaiser \& Kampe, 2005; Lundgren \& Blom, 2009), the latter with a high degree of greater exposure as it is presented on the international community's website of academics and practitioners of strategic as practice.

Thus, in order to combat the lack of studies in this emerging area, it is necessary to breach this market and perceive this activity, bringing to the academic field a considerable amount of information that contributes in a concrete way to the development of this research field and, one way is to distinguish and define the features and factors that leads to identify the uniqueness of this industry, perceiving its relationship with the market in terms of knowledge, rather than categorizing it only with a set of static applicable techniques (Fincham \& Clark, 2002; Oliver, 2018).

Taking into consideration the presented subject, this study purposes to relate two variables, the management consulting industry and its SME framework in an attempt to understand the most important factors from the consultants and managers' perspective, enabling successful relationships in management consulting projects. Curiosly clients' satisfaction with consulting firms seems to be unimportant in the consulting service market (Momparler et al., 2015). As such, this study explores the players' perception in terms of the possible benefits and costs for a good management relationship and if this accounting is done at their companies.

In this sense, the present study seeks to contribute to the development of scientific knowledge in the management consulting sector through the following objectives:
(1) see if it is possible to account for management consultants' benefits and costs of managing relationships; (2) see if this accounting for costs and benefits of managing relationships is carried out by their companies and, (3) perceive the most important factors to consider from the perspective of consultants and managers to build successful relationships in management consulting projects.

This article is divided into four parts. The first illustrates the theoretical basis of the topic, the second part the presentation of the methodology inherent to the development of this research, the third based on the obtained results and a fourth where the same will be discussed empirically. Finally, some final considerations about the study will also be presented.

\section{Literature review}

Investigating the nature, features and strategic importance of relationships in management consulting, becomes a preponderant aspect for the understanding and relevance in the construction of an increasingly important sector in terms of business. But this area continues not to have an accurate understanding or of what consultants and clients do, and especially what they do effectively together, which makes "the interactive process between consultants and clients still poorly understood" (Engwall \& Kipping, 2006, p. 8).

Since 1961, many authors have generally agreed that the relationships between consultants and clients were key aspects in a successful consulting process (Rogers, 1961; Ford, 1974; Swartz \& Lippitt, 1975; Torbert, 1976; Davey, 1979). Kürb (1976), for example, in his work mentions that consulting success consists of reading, listening, being patient and modest, and working in an organized

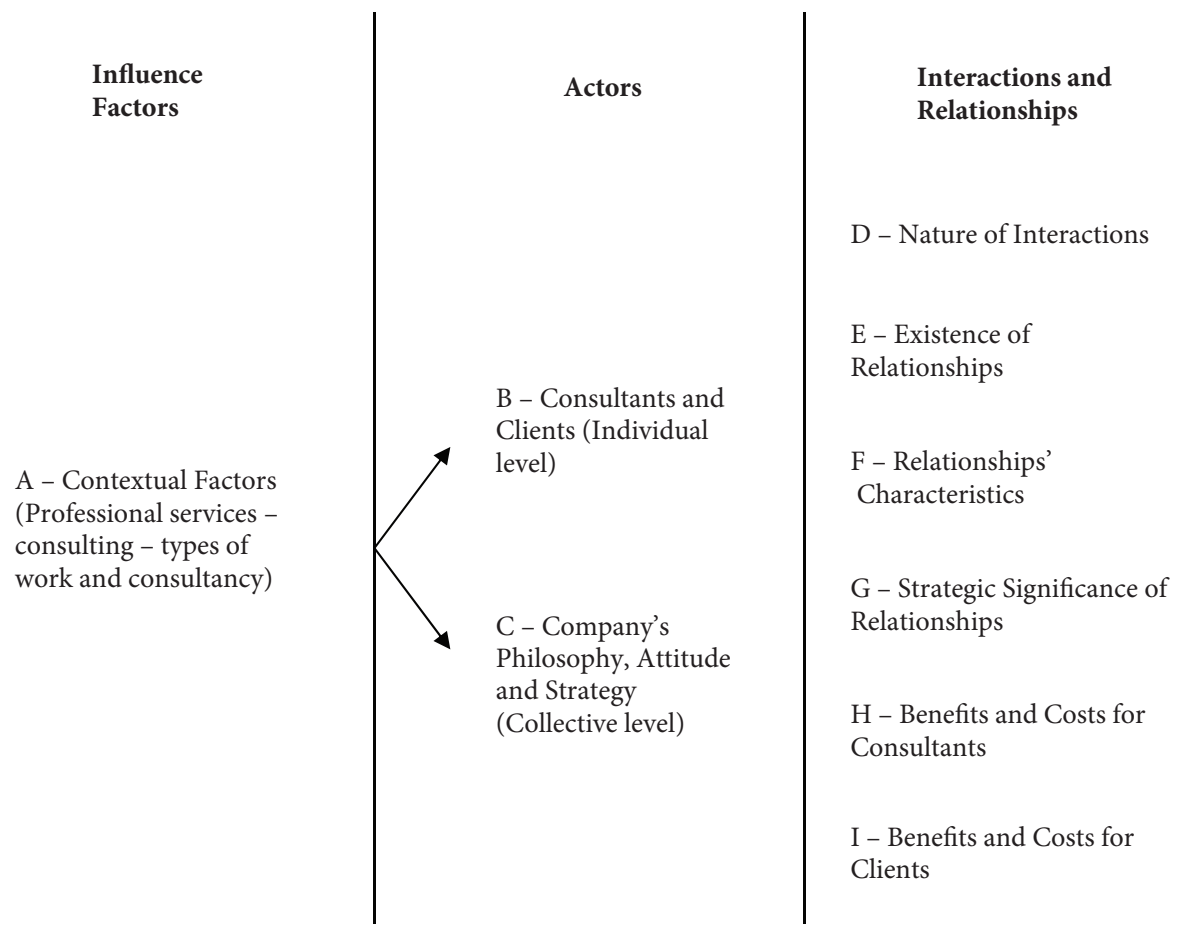

Figure 1. Conceptual structure of interactions and relationships (source: adapted from Karantinou \& Hogg, 2001) 
and disciplined way, so that the client perceives what the consultant will do and what the field of responsibility is. Therefore the author defines two fundamental aspects of consulting, the analysis and solution of the problem, and the relationship between consultants and clients. Margerison (2017) defends the need for a win-win relation for both the consultant and client.

In order to illustrate the perception about the relationships' study, Karantinou and Hogg (2001) conceived a conceptual structure of interactions and relationships. Following the theory this structure can be subdivided into three distinct axes; the factors of influence, the actors, and interactions and relationships resulting therefrom (Figure 1).

The first part of the conceptual framework involves influence factors related to relationships features, usefulness, paths and trails that must be followed by its actors. At this level it is important to distinguish the different consulting contexts, which are related to the diverse types of professional services and/or work of the same industry (strategic, operational, IT, marketing), which may require different interaction levels and relationship between the parties in building a cooperative structure and facilitating the development of effective projects.

The second part concerns the actors, from an individual or collective point of view. At a collective level, it will be important to understand how can or cannot relationships be affected by business philosophy, attitudes, behaviors and strategies. Likewise, it is important to make an identical assessment of the actors on individual issues, in particular as regards their beliefs, choices and actions that determine the existence and meaning of relationships, in an attempt to understand how the consultants come, act and manage the different types of relationships and, on the other, to perceive the perception of loyalty and relationships that are taken into account by the clients.

Finally, we have the third part of the conceptual framework, whose perspective refers to the nature of interactions themselves, the existence and relationships features, and the potential costs and benefits of these relationships as a result of the active participation of the actors' interactions (consultants and customers). So it is easy to see that management consulting has a completely different role in the complex phenomenon that involves different relationships' features. Therefore the traditional view of marketing relationships whose objective is mainly to "acquire" and regularly maintain clients that are an active part of organizational support through retention, duration (long-term links) and productivity, in a business-to-business context, where the main focus is not on relationships but on the way companies deal with those same relationships.

Compared with the first approach to traditional marketing relationships in which there is an active seller and a passive buyer, consulting relationships resemble more closely IMP's (International Marketing and Purchasing) marketing approach whose relationships must have two parts, both of which must play an active role in its development. Thus, relationships do not happen, they seek out appropriate strategies and well-selected methods and techniques, building win-win relationships where both are active actors in building long-lasting relationships.

Relationships can thus be used in a variety of different ways. Of course, business interactions can not always manage the different forms of relationships that can arise as a result of these interactions, nor does retention in itself mean a relationship. Although different studies approach different views about relationships in the consulting area, this approach is not taken for granted, and its development will always be compared with other visions in this area that allow a better understanding of the marketing and consulting relationships of management that build multiple perspectives and hypotheses by comparing these three different factors (influence factors, actors and interactions and relationships) under analysis.

In this sense, it is important to clarify a set of questions that regenerate the conceptual structure presented above, such as: the nature of the interactions, the relationship features, attitudes, philosophies and strategies of the consulting firms regarding benefits and costs of management relationships that are associated with consulting firms and clients (Karantinou \& Hogg, 2001).

According to Karantinou and Hogg (2001), it is necessary to stress out the importance of having a rigorous analysis of the costs and benefits inherent to the development of long-term relationships. Their advantages and disadvantages associated with long-term connections that also have to be taken into account. These disadvantages may include loss of excellent business opportunities, extreme dependence on particular customers, loss of outlook, annoyance, stagnation (Karantinou \& Hogg, 2001), and staff turnover. New clients can come from a freshness and invigoration of the operational plan and motivation of all professionals (Maister, 1989).

On the other side of the chain, the customers' perspective reflects the same results. Although they have different interpretations of quality (Buttle, 1997) and not all are interested in long-term relationships (Buttle, 1996), the studies by Karantinou and Hogg (2001) found that two of the main factors that must be demonstrated by consultants in building long-term relationships are empathy and honesty, although some clients fear that often their primary concern may be related to customer retention for longterm dependency purposes, neglecting the primary goal with which the need to offer effectively differentiating and efficient solutions. Recent research identified that trust, in the consultancy industry, is the resukt of: signaling ability and integrity; demonstrating benevolence; and establishing an emotional connection (Nikolova et al., 2015).

This results in the need for consultancy to study different types of relationships and in the possible development of these relationships throughout the process of transferring their knowledge, in order to diagnose clients' interests and how respective strategies can be outlined leading to success, and with mutual benefits to both parties 
(O'Farrell \& Moffat, 1991; Buttle, 1996; Gummesson, 1996; Gronroos, 1998; Karantinou \& Hogg, 2001; Karantinou \& Hogg, 2009). Furthermore, Lăzăroiu (2015) provided evidence that consultants act as transmitters of business methods, improving knowledge flow through client-consultant connections.

\section{Methodology}

The present investigation was based on a pragmatic or inductive character, and was conducted from a non-probabilistic sample of convenience, organized according to the availability and accessibility of the addressed elements (Carmo \& Ferreira, 1998), in this case by management consultants and senior managers of Portuguese SMEs. In this sense, 300 questionnaires were sent to SMEs and 350 to management consultants (including 50 independent consultants) via email. We collected 37 questionnaires from SME managers and 29 from management consultants, totaling 66 questionnaires filled out with a response rate of $10,15 \%$.
However, considering that the interest of this research was centered in determining the meaning and experiences of multiple realities, a qualitative method of analysis was also conducted by doing 17 interviews, 9 with senior management consultants and 8 managers of SMEs in Portugal, and the sample was intentional, since the participants are the ones that best represent the investigated phenomenon in terms of knowledge.

In terms of the qualitative analysis, the reproduced data from the interviews was translated into a content analysis, trying to relate the semantic structures (meaningful) with the sociological structures (meanings) of the utterances, in order to articulate the text surface with the factors that determine their characteristics - psychosocial variables, cultural context, context, processes and reproduction of the message (Figure 2).

To sumup, this research was based on a set of primary sources, from the application of surveys in the form of 17 semi-structured interviews to 9 consultants and 8 managers of SMEs and questionnaires with open and closed questions to 29 consultants and 37 managers SME, being

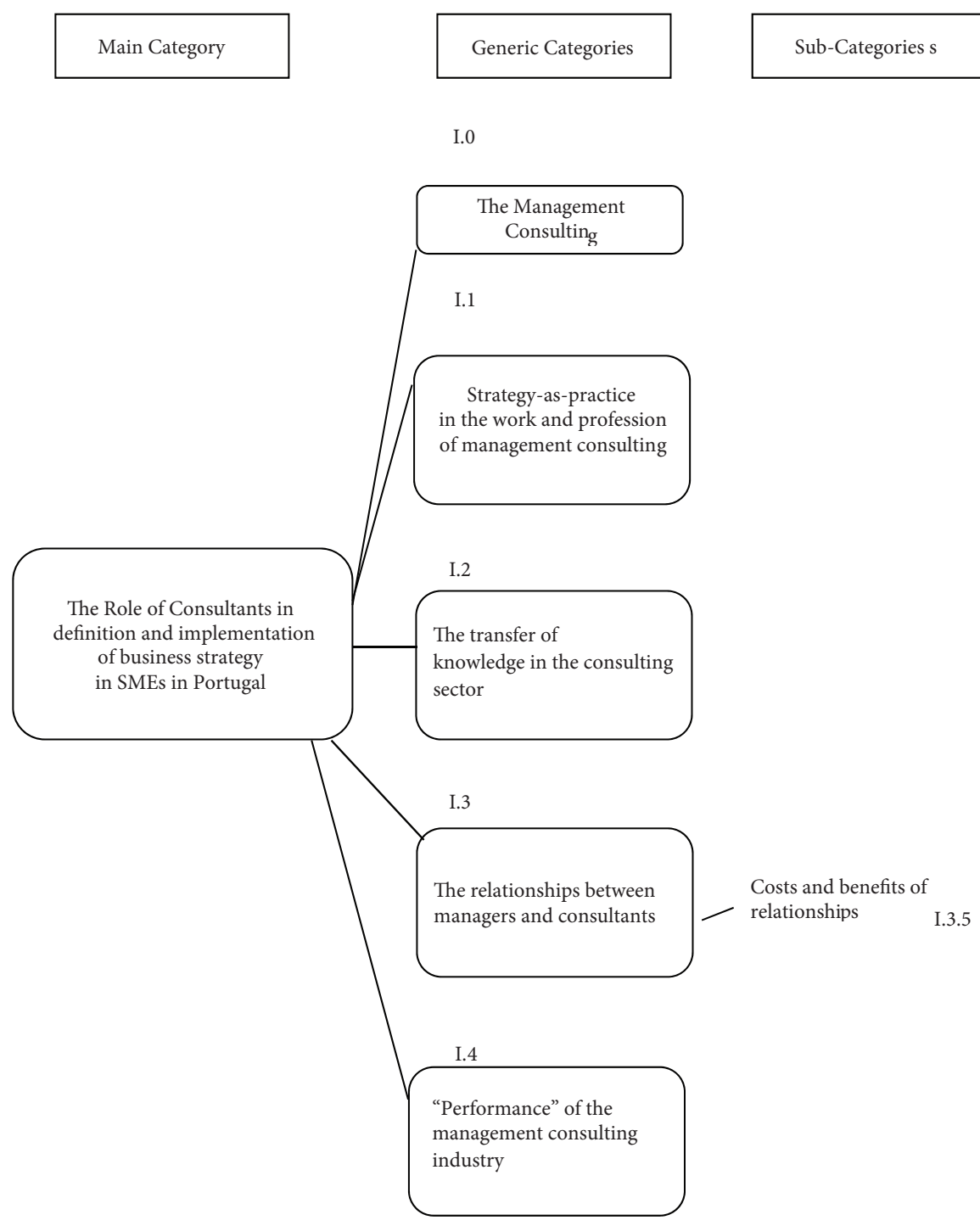

Figure 2. Categorization and coding of the interview corpus for qualitative analysis 
the representative sample predominantly male (63\%), whose ages have an arithmetic average value of 37 years of age. Almost all respondents have a higer education level and have been working in their current companies on average for about 8 years. It should also be noted that the SME sample is fundamentally linked to retail and consulting area of the most diverse sectors that make up the business management area.

\section{Results}

In Portugal, although most of the consulting firms mentioned that they account for the effects of relationships regarding benefits and costs from their management (Figure 3), and that this is done in their companies (Figure 4), allows to understand that the measurement values relationships in terms of proximity strategies with clients and not of concerning accounting, although, as mentioned by some interviewees - Content analysis (Table 1) it is possible to perform this type of accounting through comparisons between those who encourage relationships and those who do not, comparing induced actions that allow us to perceive the billing differential, the correlation between customer satisfaction and revenue, correlation between business growth, relationship quality and different relational patterns measurement.

It is possible to account for relationships' benefits and costs
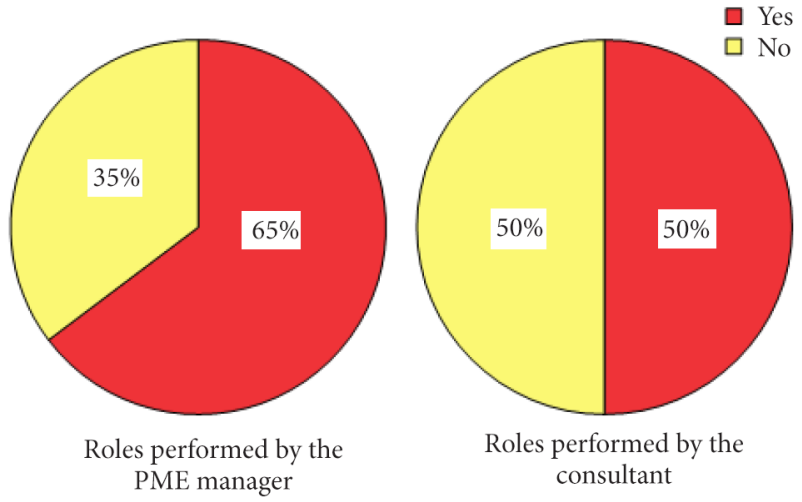

Figure 3. Evaluation of the measuring for benefits and costs of managing relationships ${ }^{1}$

Table 1 and 2 summarizes the responses obtained. Through the obtained responses it was possible to comprise that consultants' competence and experience, their ability to understand clients, their professionalism and credibility, and processes, values and objectives' transparency that they can put in the performance of their job, are the five key factors for building successful relationships.

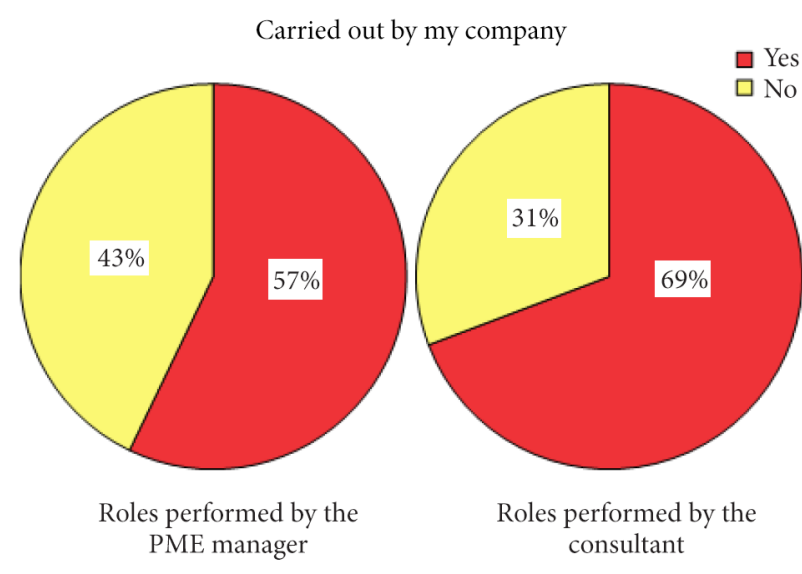

Figure 4. Evaluation of the benefits and costs of management of relationships ${ }^{2}$

Table 1. Content analysis - accounting for relationships' costs and benefits in a management consulting project (source: the authors)

\begin{tabular}{|c|c|c|c|}
\hline \multicolumn{4}{|c|}{ Content Analysis - Interviews } \\
\hline $\begin{array}{l}\text { In- } \\
\text { ter- } \\
\text { vie- } \\
\text { wee }\end{array}$ & Text & $\begin{array}{c}\text { Ge- } \\
\text { neric } \\
\text { Cate- } \\
\text { gories }\end{array}$ & $\begin{array}{c}\text { Sub } \\
\mathrm{Ca}- \\
\text { tego- } \\
\text { ries }\end{array}$ \\
\hline $\begin{array}{l}\text { Con- } \\
\text { sul- } \\
\text { tant } \\
6\end{array}$ & $\begin{array}{l}\text { It had to be a measurement over the } \\
\text { years, like the ones that foster more } \\
\text { customer relationships. Do those who } \\
\text { foster relationships sell more or less } \\
\text { projects than those who do not? }\end{array}$ & 1.3 & 1.3 .5 \\
\hline $\begin{array}{l}\text { Con- } \\
\text { sul- } \\
\text { tant } \\
6\end{array}$ & $\begin{array}{l}\text { I think it's all possible to quantify, it's a } \\
\text { matter of setting standards and rules. } \\
\text { How much the company was invoiced } \\
\text { to date and how much it came to bill } \\
\text { after a certain period, after applying } \\
\text { certain types of actions induced by the } \\
\text { consultant. The volume of jobs created, } \\
\text { what markets are doing, a local SME } \\
\text { that has become regional or national, or } \\
\text { is internationalizing. This is measurable. } \\
\text { Number of employees. Existing } \\
\text { technological level. Certified products. A } \\
\text { series of more or less objective metrics, } \\
\text { which can be objectively quantified, } \\
\text { that measures the impact of consulting } \\
\text { in an organization. It's possible. Now, } \\
\text { the relationship can also be measured } \\
\text { through leadership analysis techniques. } \\
\text { Behavioral leadership changes, there } \\
\text { have been minutes, structured meetings, } \\
\text { cyclical meetings, and this can be } \\
\text { quantified with a metric. In a period } \\
\text { between one and three years it is possible } \\
\text { to quantify evolution. }\end{array}$ & 1.3 & 1.3 .5 \\
\hline
\end{tabular}


End of Table 1

\begin{tabular}{|l|l|l|c|}
\hline \multicolumn{3}{|c|}{ Content Analysis - Interviews } \\
$\begin{array}{c}\text { In- } \\
\text { vie- } \\
\text { wee }\end{array}$ & \multicolumn{1}{|c|}{ Text } & $\begin{array}{c}\text { Ge- } \\
\text { neric } \\
\text { Cate- } \\
\text { gories }\end{array}$ & $\begin{array}{c}\text { Sub } \\
\text { Ca- } \\
\text { tego- } \\
\text { ries }\end{array}$ \\
\hline $\begin{array}{l}\text { Con- } \\
\text { sul- } \\
\text { tant }\end{array}$ & $\begin{array}{l}\text { The problem is to decouple things. } \\
\text { What is the impact of having a better } \\
\text { relationship in the business? It is } \\
\text { difficult to quantify. Now there are a } \\
\text { few things clear, there is one thing we } \\
\text { could do, like customer surveys, to } \\
\text { correlate customer satisfaction with } \\
\text { project revenue on that account. Now in } \\
\text { terms of the relationship. The key is to } \\
\text { move from the supplier relationship to } \\
\text { a relationship. There is a strategy, invites } \\
\text { them to events, worrying about them in } \\
\text { order to be seen as partners. Perhaps in } \\
\text { the long run go correlating the growth } \\
\text { of the business with the satisfaction and } \\
\text { quality of the relationship. But it had to } \\
\text { be measured by both parties and not just } \\
\text { by the consultant. }\end{array}$ & 1.3 .5 \\
\hline $\begin{array}{l}\text { Con- } \\
\text { sul- } \\
\text { tant } \\
8\end{array}$ & $\begin{array}{l}\text { If you did not have the consultant, where } \\
\text { the company would be? That is, until the } \\
\text { consultant had this standard, after the } \\
\text { consultant came to have this. You can try } \\
\text { to understand what influence the profile } \\
\text { of the consultant has. }\end{array}$ & \\
\hline
\end{tabular}

Finally, it was still relevant to perceive a set of important factors for the construction of successful relationships (Table 2).

Table 2. Important factors from the perspective of consultants and managers to build successful relationships in management consulting projects

\begin{tabular}{|l|c|}
\hline \multicolumn{1}{|c|}{$\begin{array}{c}\text { Important Factors for Successful Relationships } \\
\text { (consultants and clients) }\end{array}$} & Points \\
\hline Competence and experience of consultants & 164 \\
\hline Consultants ability to understand clients & 140 \\
\hline Consultants Professionalism & 112 \\
\hline Consultants' Credibility & 89 \\
\hline Processes, values and objectives' Transparency & 83 \\
\hline Developing personal and organizational trust & 64 \\
\hline Empathy and commitment & 57 \\
\hline Open minds and customer accessibility & 43 \\
\hline Careful handling of the process in terms of service & 28 \\
\hline Level of consultant's flexibility & 24 \\
\hline $\begin{array}{l}\text { Conducting and managing relationships at different } \\
\text { levels }\end{array}$ & 20 \\
\hline Similarity of organizational objectives & 11 \\
\hline Good personal relationships & 7 \\
\hline Similarity organizational philosophies & 6 \\
\hline Personal chemistry & 4 \\
\hline
\end{tabular}

Note: In this table is considered the top 5 of each respondent, after a classification of 5 - the most important to 1 the less important.

\section{Discussion}

Before we turn to the question of measurement itself, it is important to define clearly what a relationship is, which is very difficult to start with. Is this linked to social intelligence? To people's emotions? To created impacts? This is indeed a genuine and complicated concern.

To consider as a relationship these three factors, based on links that comprise long-term links and, even if one believes that with nowadays' technology can be considered unattainable (c.f. Czerniawska, 2016), the truth is that it is not easy to measure or to count the cost-effectiveness of a relationship. Similar findings were observed by Momparler et al. (2015). On the other hand, another important aspect in this context is also the fact that it is possible to do this accounting to an extent used for decision making.

These are aspects are clearly to be taken into account by the parties if they are effectively challenged, but what matters here is that there is no impossibility, and the state of the art mastery when applied to a given context can produce value, even though it may or may not be used as a decision-making. As indicated by Margerison (2017) the "consultant have to learn to manage and managers have to learno to consult" (p. 11).

In this sense, it should be kept in mind that, although a given measurement may validate data generation over long periods and that can be extended over time, everything is possible to be accounted for, and the key is always to establish standards and rules so that this can be effectively accomplished, whether it is; (1) by comparing, for a given period of time, a set of consultants who are more conducive to relations than those who are not (in order to account for the number of awards made), (2) by comparison two periods mediated by the introduction of a certain set of actions induced by the consultant in order to perceive the differential in terms of billing, (3) making a correlation between customer satisfaction and project revenue with the same client, (4) correlating business growth with relationship satisfaction and quality, and (5) including, using appropriate leadership analysis techniques, different relational patterns of the consultants during a given period, accounting for these profiles differences in terms of accounting value generated in these two balances.

What matters is that it is either the need to create references by the consultant, also because of the possibility in accounting the management quality of relationships, or for any other reason that builds constructive relationships, successfully developed relationships, based mainly on the consultants' competence and experience, their ability to understand clients, their professionalism and credibility, and mutual transparency in processes, values and objectives. Figure 5 is illustrative of a model where important factors can be pictured in order to develop successful projects and ways of effectively accounting for them.

Theoretically, this article focused on the conceptual structure of interactions and relationships between consultants and clients developed by Karantinou and Hogg (2001), namely focusing on the nature of interactions, the 


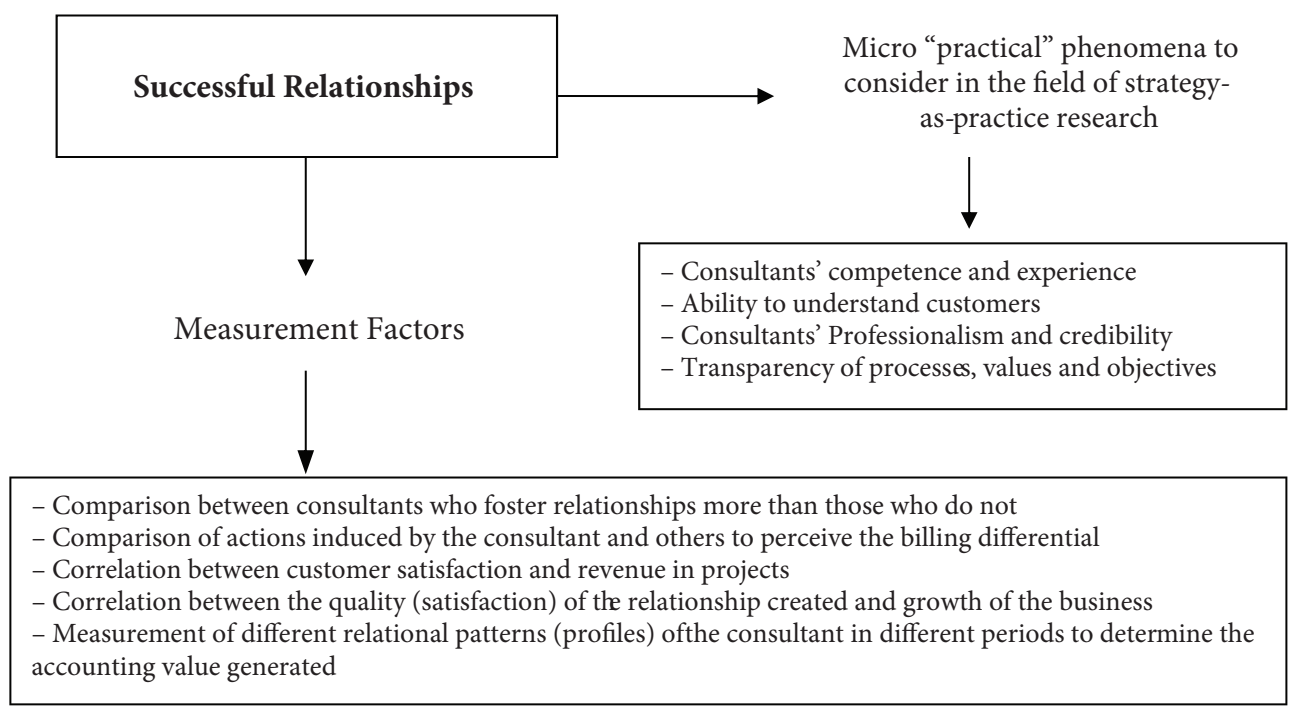

Figure 5. Building and measuring successful relationships in consultancy

existence or not of relationships, the characteristics of the relationships, their strategic significance and the benefits and costs they can bring for consultants and clients.

This model aimed to have a basis to study the different types of relationships that can develop from this interaction contributing to the development of scientific knowledge in the management consulting sector by surveying the benefits and costs taken into account in the consultant-client relationship and their respective impact on the satisfaction of the parties, to understand if in fact the impact of the relationships on the success of a work in management consulting is accounted for, and to understand with consultants and managers of companies which factors should be considered for the existence of successful consulting projects.

\section{Conclusions}

As the results of this study have shown, the role of the consultant in this study must be linked to pragmatism, objectivity, rigor and necessity. All these criteria must be oriented towards objectives and results based on a strategic vision and regardless of the different control assumptions that may be implicit in the type of developed project, or of the different types of SMEs that may be involved in this context, what is important is that successful relationships are kept, fundamentally linked to consultants' competence and experience, their ability to understand clients, their professionalism and credibility, and in mutual transparency in processes, values and objectives.

The important thing to keep in mind is that consultants should in fact create references and have concerns about the preliminary advantages of relationships in terms of continuity and consistency (these must be built "within projects", "between projects", but also "before projects"), since they are the basis for what is going to be constructed in terms of efficiency in and out of action, and this base must result from attention in increasing the performance of a certain activity that needs to be improved, attention to the building strategies, concentrating efforts on the areas of concern and, essentially, identifying the client and the business and identifying their interests, values, attitudes and visions.

It can thus be said that relationships can be used in different ways, and the important thing is to clarify a set of questions in terms of the nature of their interactions, but also on other types of issues that may result in a greater degree of complicity, proximity and openness between consulting firms and clients, for example, suggesting performance improvements that may validate higher levels of performance in the future, such as those presented by this research.

In this case, as suggested by managers, what should be improved from the point of view of process consulting would be a closer link between the business and technical part, better use of skills, knowledge and accountability of people by focusing on them specifically in areas of expertise where they can achieve better levels of performance, the consultants serve as catalysts in order to question and show higher levels of interest in the success of the work they develop, and still have the capacity to develop means for a more detailed monitoring and permanent communication during the whole project phase, and a more effective and efficient communication, which most of the time does not happen. From the operational point of view, only accept projects in which they have specialized knowledge and that can add real value to their clients and, in a strategic scope, to be able to present mathematically perfect models that are consistent with reality, sometimes it does not happen either.

It is important, however, to take into account that the findings presented in this study are the result of limitations inherent to a small investigation in terms of sample size (respondents) and of replicating results in a particular 
context (SMEs) in a particular country (Portugal).

In this sense, in terms of external validity, i.e. the possibility of generalizing the results to other contexts or samples, although this study has reinforced some of the existing theory regarding the concept of management consulting, this was only an exploratory study that can not be generalized or representative.

On the other hand, although the secondary sources have been used and other analyzes have been elaborated to complete the results, this factor can not justify that the results presented here can be seen as necessarily generalizable in terms of the consulting practice.

Another of the limitations was linked to the impossibility of observing "in loco" client-consultant interactions and, therefore, the consequent peculiarities of problems, ideas and techniques that could result from this same interaction.

Although this article aims fundamentally to combat the lack of studies on the management consulting industry, it is necessary to continue to penetrate this market and to perceive this activity, bringing to the academic field a considerable amount of information that brings above all originality and contribute in a concrete way to the development of this field of research.

One of the ways to respond to this gap is to focus, establish and institutionalize the practices and activities used in the management consulting industry and their implications in terms of organizational results, seeking to obtain a set of new developments in construction of literature with the introduction of new theoretical and empirical perspectives in this area.

In short, it is important to extend these studies to a deeper basis on all these subjects, in order to explore the future of the nature of practices, activities, stages and relationships in the management consulting industry, and future research to include in this sense the construction of a model that allows to relate all these variables, in order to be able to identify which one is more determinant for the success of a management consulting project. The ongoing task of the study of the sector should not forget also the impact that all this can have downstream of the chain, namely to the degree of satisfaction of the client companies with the work done by the consultants and of the suggestions they advise for the improvement of the achievements.

\section{Declaration of conflicting interests}

The author(s) declared no potential conflicts of interest with respect to the research, authorship, and/or publication of this article.

\section{Funding}

The author(s) received no financial support for the research, authorship, and/or publication of this article.

Note: We are able to make available, upon request, the data and for a period of five years after publication to other researchers interested in replicating and/or extending the work.

\section{References}

Biech, E. (2019). The new business of consulting: the basics and beyond. John Wiley \& Sons.

Buttle, F. (1996). Relationship marketing: theory and practice. Paul Chapman Publishing. https://doi.org/10.4135/9781446252062

Buttle, F. (1997). Exploring relationship quality, em marketing without borders. Annual Academy of Marketing Conference Proceedings (July) (pp. 143-155). Manchester.

Canback, S. (1998). The logic of management consulting (part one). Journal of Management Consulting, 10(2), 3-11.

Canback, S. (1999). The logic of management consulting (part two). Journal of Management Consulting, 10(3), 3-12.

Clark, T. (2004). Strategy viewed from a management fashion perspective. European Management Review, 1(1), 105-111. https://doi.org/10.1057/palgrave.emr.1500004

Carmo, H., \& Ferreira, M. (1998). Metodologia da Investigação: Guia para Auto-aprendizagem. Universidade Aberta, Lisboa.

Czerniawska, F. (2016). Management consultancy: what next? Springer.

Davey, N. (1979). The consultant's role. Organizational change in the client consultant handbook. Gulf.

Drucker, P. F. (1979). Why management consultants? In Z. Melvin and R. G. Greenwood (Eds.), The Evolving Science of Management. AMACOM, New York, NY.

Engwall, L., \& Kipping, M. (2006). Management education, media and consulting and the creation of European management practice. Innovation: The European Journal of Social Science Research, 19(1), 95-106. https://doi.org/10.1080/13511610600607973

Fincham, R. (2010). The client in the client-consultant relationship. In M. Clark, \& T. Kipping (Eds.), The Oxford handbook of management consultancy. Oxford University Press. https://doi.org/10.1080/00208825.2002.11043673

Fincham, R., \& Clark, T. (2002). Preface: management consultancy - issues, perspectives and agendas. International Studies of management and Organization, 32(4), 3-18. https://doi.org/10.1080/00208825.2002.11043673

Fincham, R., Clark, T., Handley, C., \& Sturdy, A. (2008). Configuring expert knowledge: the consultant as sector specialist. Journal of Organizational Behaviour, 29(8), 1145-1160. https://doi.org/10.1002/job.559

Ford, C. (1974). Developing a successful client-consultant relationship. Human Resource Management (pre-1986), 13(2), 2. https://doi.org/10.1002/hrm.3930130202

Greiner, L., \& Metzger, R. (1983). Consulting to management. Prentice-Hall.

Gronroos, C. (1998). Marketing services: The case of the missing product. Journal of Business and Industrial Marketing, 13(4/5), 322-338. https://doi.org/10.1108/08858629810226645

Gummesson, E. (1996). Relationship marketing and imaginary organisations: A synthesis. European Journal of Marketing, 30(2), 31-44. https://doi.org/10.1108/03090569610106635

Jackall, R. (1988). Moral mazes - the world of corporate managers. OU. https://doi.org/10.1007/BF01390690

Jarzabkowski, P., Balogun, J., \& Seidl, D. (2007). Strategizing: The challenges of a practice perspective. Human Relations, 60(1), 5-27. https://doi.org/10.1177/0018726707075703

Jarzabkowski, P., \& Spee, P. (2009). Strategy-as-practice: A review and future directions for the field. International Journal of Management Reviews, 11(1), 69-95. https://doi.org/10.1111/ j.1468-2370.2008.00250.x 
Kaiser, S., \& Kampe, T. (2005). A strategy-as-practice perspective on the work of profession of strategy consultants. EGOS, Professional Service Organizations and Professionalization at Work. Berlin, Germany.

Karantinou, K., \& Hogg, M. (2001). Exploring relationship management in professional services - A study of management consultancy. Journal of Marketing Management, 17(3-4), 263-86.

Karantinou, K., \& Hogg, M. (2009). An empirical investigation of relationship development in professional business services. Journal of Services Marketing, 23(4), 249-260. https://doi.org/10.1108/08876040910965584

Kürb, M. (1976). Management consulting: a guide to the profession. International Labour Office, $1^{\text {a }}$ Edição: Geneva.

Lăzăroiu, G. (2015). The role of the management consultancy industry in the knowledge economy. Psychosociological Issues in Human Resource Management, 3(2), 71-76.

Lundgren, M., \& Blom, M. (2009, July 2-4). The practice of strategy consultants. In 25th Egos Colloquium. Barcelona.

Maister, D. (1989). Marketing to existing clients. Journal of Management Consulting, 5(2), 25-32.

Margerison, C. J. (2017). Managerial consulting skills: a practical guide: a practical guide. Gower Publishing, Ltd. https://doi.org/10.4324/9781315187631

McGivern, C. (1983). Some facets of the relationship between consultants and clients in organizations. Journal of Management Studies, 20(3), 367-386. https://doi.org/10.1111/j.1467-6486.1983.tb00213.x

McLarty, R., \& Robinson, T. (1998). The practice of consultancy and a professional development strategy. Leadership and Organisation Development Journal, 19(5), 256-263. https://doi.org/10.1108/01437739810234323

Momparler, A., Carmona, P., \& Lassala, C. (2015). Quality of consulting services and consulting fees. Journal of Business Research, 68(7), 1458-1462.

https://doi.org/10.1016/j.jbusres.2015.01.033
Nikolova, N., Möllering, G., \& Reihlen, M. (2015). Trusting as a "leap of faith": Trust-building practices in client-consultant relationships. Scandinavian Journal of Management, 31(2), 232-245. https://doi.org/10.1016/j.scaman.2014.09.007

O’Farrell, P., \& Moffat, L. (1991). An interaction model of business service production and consumption. British Journal of Management, 2, 205-221.

https://doi.org/10.1111/j.1467-8551.1991.tb00027.x

Oliver, C. (2018). Reflexive inquiry: A framework for consultancy practice. Routledge. https://doi.org/10.4324/9780429479472

Rogers, C. (1961). The characteristics of a helping relationship. Houghton Mifllin.

Stryker, P. (1954). The ambitious consultants. Fortune (May), $82-85$.

Sturdy, A. (2009). Popular consultancy critiques and a politics of management learning? Management Learning, 40(4), 457463. https://doi.org/10.1177/1350507609339686

Swartz, D., \& Lippitt, G. (1975). Evaluating consulting process. Journal of European training, 4(5), 309-326.

Torbert, W. (1976). Creating a community of inquiry: conflict, collaboration, transformation. Wiley Interscience.

Werr, A., \& Styhre, A. (2002). Management consultants friend or foe? International Studies of Management \& Organization, 32(4), 43-66. https://doi.org/10.1080/00208825.2002.11043670

Whittington, R. (2006). Completing the practice turn in strategy research. Organization Studies, 27(5), 613-634. https://doi.org/10.1177/0170840606064101

Whittington, R. (2007). Strategy practice and strategy process: Family differences and the sociological eye. Organization Studies, 28(10), 1575-1586.

https://doi.org/10.1177/0170840607081557 